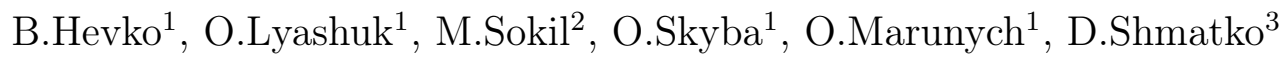 \\ ${ }^{1}$ Ivan Pul'uj Ternopil National Technical University, Ukraine; \\ ${ }^{2}$ Lviv National Polytechnic University, Ukraine; \\ ${ }^{3}$ Dneprodzerzhinsk State Technical University, Ukraine \\ (E-mail: Oleglashuk@ukr.net)
}

\title{
Dynamics of auger working body of a multifunctional conveyor
}

\begin{abstract}
A mathematical model of bending oscillations of a multifunctional conveyor working body with consideration of the angular velocity of its rotation and the motion along its outdoor medium is developed. Based on this model, the analytical relations were defined that describe the laws of changing the defining parameters of the working body oscillations for both non-resonant and resonant cases. The amplitude of the transition through the resonance is found to depend greatly on the relative quantity of medium motion and the rate of transition through the resonance.
\end{abstract}

Keywords: dynamic modeling, amplitude, resonance, conveyor, determining parameters, speed of rotation.

\section{Introduction}

The auger working body of the multifunctional conveyor in the operating mode undergoes considerable dynamic loads due to a simultaneous effect of longitudinal compressive force (transmitted from moving regulating blocks), external driving moment, and the forces of interaction with the processed medium. The indicated power factors cause complex oscillations in the body, that is a combination of torsion, longitudinal, and bending ones. The transverse oscillations to a certain extent reduce the service life of the auger, and also create additional dynamic loads on a «fixed» cone trough. Moreover, the processed medium when moving at a certain speed relative to the auger working body causes an additional dynamic effect. This effect is largely manifested for its bending oscillations. In addition, the heterogeneous inclusions always occur in the processed medium or in the medium being transported. Due to the rotational movement of the working body, they «block» it up in separate points, thereby causing additional power actions in them. On the other hand, based on these factors, the mathematical model of the relative motion dynamics of the system 'elastic body - medium moving flow' acquires a qualitatively new consideration [1-3], for which, in the general case, the known analytical methods of studying the systems with distributed parameters cannot be applied [4]. The first two types of oscillations (in some cases) contribute to the technological process improvement, in particular the adhesion prevention of the processed medium, its additional densification, and the structure perfection) [5-10]. The application of numerical simulation methods does not lead to the desired results due to the complexity of systems, in particular the most dangerous resonant oscillations of the working body. In this paper, the main attention is paid to the development of approximate analytical methods for studying bending oscillations of the multifunctional conveyor working body, which rotates with a constant angular velocity around the longitudinal axis; and a continuous flow of the processed medium moves along it. Resonant and non-resonant cases are considered as well.

\section{Material and method}

The auger compensating multifunctional conveyor is made in the form of a casing (1) with both front (2) and rear (3) supports (Fig. 1). Their height can be changed in order to transport materials horizontally and at an angle. The fixed cone trough (4) is firmly fixed to these two supports in several variants - the solid one and with the system of through-holes in its lower part made in a known way. Inside the fixed conical body metricconverterProductID4, a4, a conical screw working element (5) with variable steps is installed in the bearing units with the possibility of turning and axial displacement. The bearing bushes 5 are welded to the left (2) and the right (3) supports; in their central openings, the movable cylindrical blocks (6) are set. The bearings are rigidly installed in the middle of blocks; the internal holes of bearing are in contact with the shaft (7) ends of the conical auger (5) with the possibility of axial displacement. 


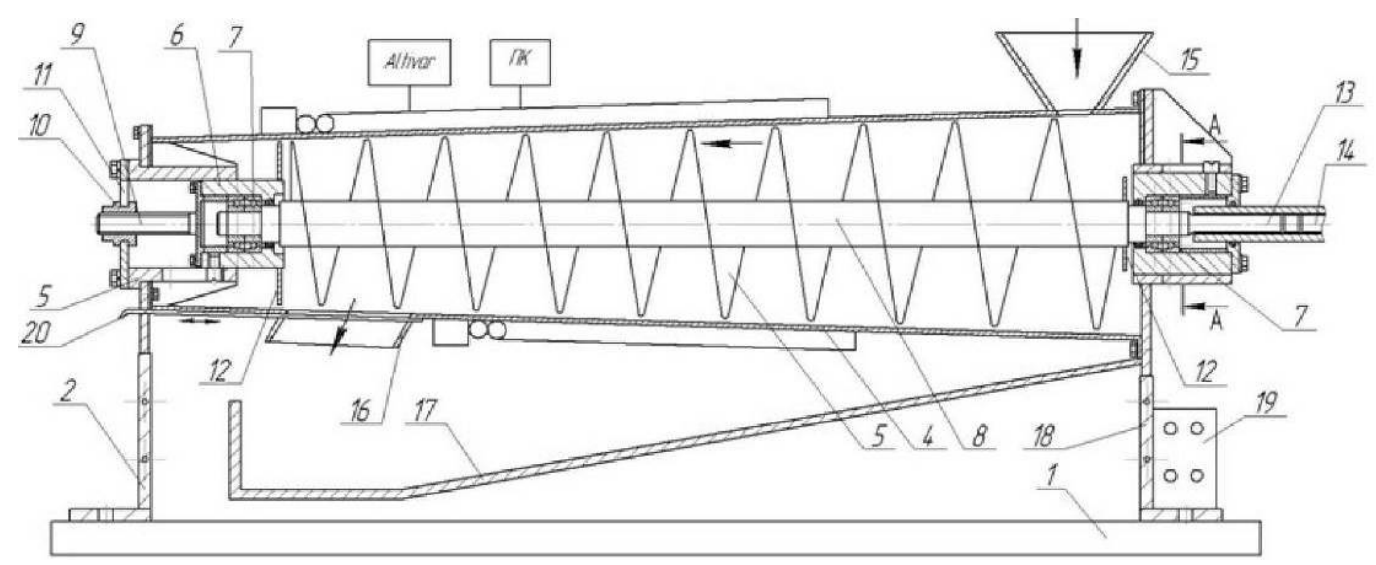

Figure 1. Schematic construction of auger compensating multifunction conveyor

The ends of movable blocks (6) are covered with lids. A screw (9) is rigidly welded to the left lid (8) of the cylindrical block (6). The screw is in contact with the adjusting nut 10, which is firmly mounted in the axial groove of the lid (11) of the movable cylinder block metricconverterProductID6. In6. In addition, the stopper (13) are firmly fixed to the left and right ends of the shaft (7) of the cylindrical movable block (6). They prevent the movement of transport mass beyond the screw working body.

Similarly, at the right end of the screw cone working body, the structure is the same, but the difference is that the ends of the shaft (7) are made with an elongated cut (14), to which the drive shaft (15) of the conveyor is connected. In the loading zone, the boot pipe (16) is installed, and in the unloading zone, the discharge nozzle (17) is installed as well. To fix the screw conical working body metric converter ProductID5, in5, in the moving blocks (6), the axial slots (19) are made with screw fixing elements (20). The system is controlled from the console (21).

Depending on operations, a stationary pipe is chosen. Thus, let us consider the operation of the conveyor for squeezing the juice. For this purpose, the inclination angle should be set by reducing the height of the left support in a known way. The stationary pipe is chosen with through-holes and the corresponding design of a conical screw working body with an appropriate gap between the holes and the stationary pipe; the gap is set with the help of an adjustor nut. The materials, from which the juice will be squeezed, are loaded into the boot pipe. A conveyor is started and the appropriate modes of operation are set on the control panel. The squeezed juice flows into a container and a trench through a through-hole system, then it is taken away. The pulp is collected through a discharge nozzle into a separate container with the help of a sliding shutter.

A multifunctional conveyor screw working body rotates with a constant angular velocity $\omega$; the continuous flow of the processed medium moves along it at a relative speed $V$. Thus, the challenge is to determine the influence of external and internal factors on the transverse oscillations of the working body.

Basic assumptions about the object under study:

- the auger working body is the elastic body, which is symmetric relative to the longitudinal axis; its material satisfies the nonlinear technical law of elasticity [11] $-\sigma=E\left(\varepsilon_{1}+\varepsilon \varepsilon_{1}^{3}\right)\left(\varepsilon_{1}\right.$ - relative deformation, the parameter $\varepsilon$ characterizes the deviation of its elastic properties from the linear law; it is considered small in comparison with the elastic modulus $E$ );

- its inertia moment relative to the longitudinal axis $O X$ is $I(x)$; its mass per unit length $m_{1}(x)$ rotates with a constant angular velocity around the longitudinal axis inclined to the horizon at an angle $\alpha ; u(x, t)$ - transverse displacement of its neutral axis with the coordinate $x$ at any given time $t$ ( $O X$ axis is deduced from the upper bearing along the undeformed axis of the screw working body); the deplanation of the normal cross-section is absent.

The processed medium is not an elastic solid body [12-14] with a mass per unit length $m(x)$. Mathematical model of the object under study: based on the above [11,15], the differential equation of bending oscillations of the multifunctional conveyor working body, along which the continuous flow of the processed medium moves, is deduced 


$$
\begin{aligned}
\left(m_{1}\right. & +m)\left(\frac{\partial^{2} u(x, t)}{\partial t^{2}}+\omega^{2} u(x, t)\right)+2 m V \frac{\partial^{2} u(x, t)}{\partial t \partial x}+\left(m V^{2}+N\right) \frac{\partial^{2} u(x, t)}{\partial x^{2}}+\lambda\left(\frac{\partial u(x, t)}{\partial t}\right)^{s}+ \\
& +\frac{\partial}{\partial x}\left[\frac{\partial}{\partial x}\left(E I(x)\left(\frac{\partial^{2} u(x, t)}{\partial x^{2}}+\varepsilon\left(\frac{\partial^{2} u(x, t)}{\partial x^{2}}\right)^{3}\right)\right)\right]=H \sin ^{2 q}\left(\omega t+\varphi_{0}\right) \delta\left(x-x_{0}\right)
\end{aligned}
$$

where $N$ - pressure forces at the auger end; $\lambda, s, x_{0}, \varphi_{0} ; H$ - steels; $\delta\left(x-x_{0}\right)$ - Delta Dirac's function. Dependence $\lambda\left(\frac{\partial u(x, t)}{\partial t}\right)^{s}$ describes the resistance force to the working body motion; and the ratio $H \sin ^{2 q}(\omega t+\vartheta) \delta\left(x-x_{0}\right)$ describes the interaction force of the heterogeneous inclusion and the working body $\left(q=1,2, \ldots ; x_{0}\right.$ indicates the location of the heterogeneous inclusion, and $q$ - its form).

To describe the dynamic process of the system under consideration, the boundary conditions are added to the equation (1) that for simplicity are assumed in the form

$$
\left.u(x, t)\right|_{x=0 ; l}=\left.\frac{\partial^{2} u(x, t)}{\partial x^{2}}\right|_{x=0 ; l}
$$

where $l$ - the distance between the upper and lower bearings of the working body.

To solve this problem, for the above-mentioned mathematical model of the dynamics process, it is necessary to develop the basic analytical dependences for determining the law of changing the defining parameters of the oscillation process, depending on the external and internal factors of the system.

To solve the first part of the problem, we will make additional physically based assumptions about force factors: a) the maximum values of the resistance forces and the interaction force of the inhomogeneous inclusion with the working body is a small value in comparison with the maximum value of the second or fourth terms of the left-hand side of the equation $(1)$; b) the motion quantity of the processed medium in the relative motion (in relation to the working body) is a limited quantity; c) inertia moment of the working body is a slowly varying function; and its change along the length is neglected. Thus, the differential equation (1) is deduced:

$$
\begin{gathered}
\left.\frac{\partial^{2} u(x, t)}{\partial t^{2}}+\omega^{2} u(x, t)\right)+\frac{N}{m_{1}+m} \frac{\partial^{2} u(x, t)}{\partial x^{2}}+\frac{E I}{m_{1}+m} \frac{\partial^{4} u(x, t)}{\partial x^{4}}= \\
=\frac{1}{m_{1}+m}\left(H \sin ^{2 q}\left(\omega t+\varphi_{0}\right) \delta\left(x-x_{0}\right)-\lambda\left(\frac{\partial u(x, t)}{\partial t}\right)^{s}-\right. \\
\left.-m V^{2} \frac{\partial^{2} u(x, t)}{\partial x^{2}}-2 m V \frac{\partial^{2} u(x, t)}{\partial t \partial x}-\varepsilon E I \frac{\partial^{2}}{\partial x^{2}}\left(\frac{\partial^{2} u(x, t)}{\partial x^{2}}\right)^{3}\right) .
\end{gathered}
$$

Based on the above limitations for the system under study, the maximum value of the right-hand side of the equation is small in comparison with the maximum value of the terms of its left-hand side. The latter, in turn, is the basis for solving the boundary problem (3), (2) of combining the Bubnov-Galerkin method [9] and the Van der Paul method [15]. The first one-frequency approximation in modes close to the principal oscillation mode can be presented as $u(x, t)=\sin \frac{\pi}{l} x T(t)$, where $T(t)$ is an unknown function; this function is the solution of the common quasi-linear differential equation

$$
\begin{gathered}
\ddot{T}(t)+\Omega^{2} T(t)= \\
=-\frac{\bar{\lambda}}{m+m_{1}} \dot{T}^{s}+\frac{m V^{2}}{\left(m+m_{1}\right)}\left(\frac{\pi}{\ell}\right)^{2} T+\frac{3 \varepsilon E I}{32}\left(\frac{\pi}{\ell}\right)^{6} T^{3}+\frac{H}{\ell\left(m+m_{1}\right)} \sin \frac{\pi x_{0}}{\ell} \sin ^{2 q}\left(\omega t+\varphi_{0}\right),
\end{gathered}
$$

where $\Omega^{2}=\frac{E I}{\left(m+m_{1}\right)}\left(\frac{\pi}{\ell}\right)^{4}-\omega^{2}-\frac{N}{\left(m+m_{1}\right)}\left(\frac{\pi}{\ell}\right)^{2}, \bar{\lambda}=\lambda \frac{\Gamma(1+s / 2)}{2 \Gamma(1.5+s / 2)}$.

According to the principle of one-frequency oscillations in nonlinear systems [16], the dynamic process in the mode close to the first mode of the «dynamic equilibrium» of the object under study is analyzed. This process is considered the most important in view of practical use. 


\section{Results}

The right-hand side of the equation (4) is periodic in time with the period $\frac{\pi}{\omega}$. Then, the resonance in the system can occur in case of a certain correlation between the frequency of the own (unperturbed) oscillations of the working body and the angular velocity of its rotation, and, therefore, a periodic perturbation. Thus, both resonant $\Omega \approx 2 \omega$ and non-resonant $\Omega \neq 2 \omega$ cases should be considered to solve the equation (4). In this paper, only the case of the main resonance is considered; the consideration of the combination or fractional resonance does not constitute a fundamental difference. Based on the above, the main resonance in the auger working body occurs at the next angular velocity of its rotation (Fig. 2)

$$
\omega=\frac{\pi}{\sqrt{5}}\left(\frac{E I}{\left(m+m_{1}\right)}\left(\frac{\pi}{\ell}\right)^{2}-\frac{N}{\left(m+m_{1}\right)}\right)^{\frac{1}{2}} .
$$
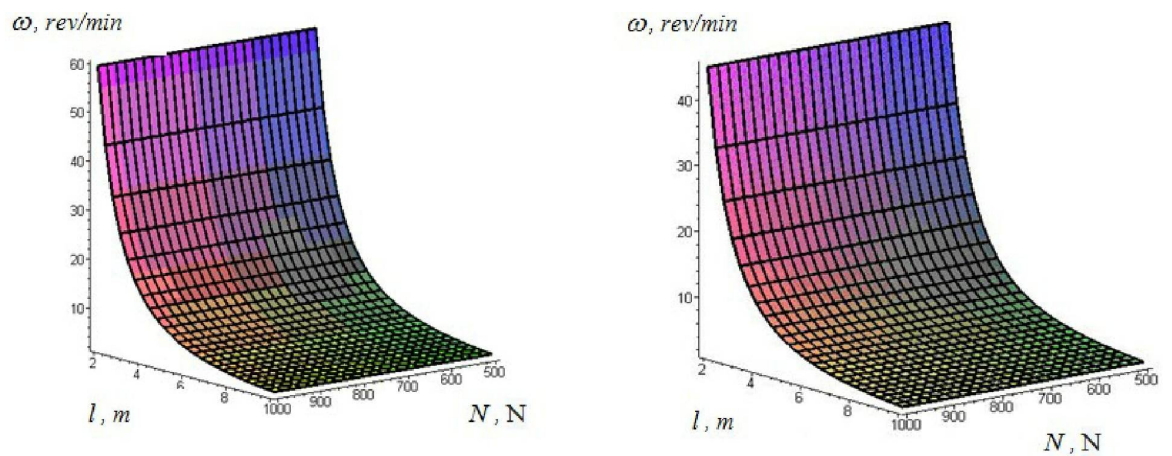

Figure 2. Dependence of the angular velocity of the working body rotation on its length and compressive force

The oscillations amplitudes, for the non-resonant case, do not depend on the external perturbation [15, 16] and are determined by the ratio

$$
\frac{d a}{d t}=\frac{1}{\pi \Omega} \int_{0}^{2 \pi} \int_{0}^{2 \pi}\{F(a, \psi, \varphi)\} \cos \psi d \varphi d \psi,
$$

where $F(a, \psi, \varphi)$ corresponds to the value of the right-hand side of the equation (4), and $T=a \cos \psi, \psi=\Omega t+\psi_{0}$. Thus, for perturbed motion, the laws of changes in the amplitude of non-resonant oscillations are deduced

$$
\frac{d a}{d t}=\frac{\lambda}{\sqrt{\pi} \Omega} \frac{\Gamma(1+s / 2)}{2 \Gamma(1.5+s / 2)} a^{s}
$$

A resonant case is more difficult to study, and at the same time it is more important in view of practical use. For this case, the amplitude of the transition through resonance depends to a large extent on the difference between the phases of the own and forced oscillations, that is, the parameter $\gamma=\psi-\varphi, \varphi=\omega t$. The relations that describe the laws of changing the basic parameters of the working body during the transition through the main resonance are developed:

$$
\begin{gathered}
\frac{d a}{d t}=\frac{\lambda}{\pi \Omega} \frac{2(1+\mathrm{s} / 2)}{2(1.5+\mathrm{s} / 2)} a^{s}-\frac{H}{\left(m+m_{1}\right)(\Omega+\omega)} \frac{2 q}{2+q} \frac{\Gamma((2 q+1) / 2)}{\Gamma(1+q / 2)} \sin \gamma \sin \frac{\pi x_{0}}{\ell} \\
\frac{d \gamma}{d t}=\Omega-\omega / 2-\frac{m V^{2}}{2\left(m+m_{1}\right) \Omega}+\frac{0.07 \varepsilon E I \pi}{\left(m+m_{1}\right)} a^{2}+ \\
+\frac{H}{\left(m+m_{1}\right)(\Omega+\omega)} \frac{2 q}{2+q} \frac{\Gamma((2 q+1) / 2)}{\Gamma(1+q / 2)} \cos \gamma \sin \frac{\pi x_{0}}{\ell}
\end{gathered}
$$

In Figure 3, the dependences of the change in time of the transverse oscillations amplitude at different values of the system parameters are represented. 


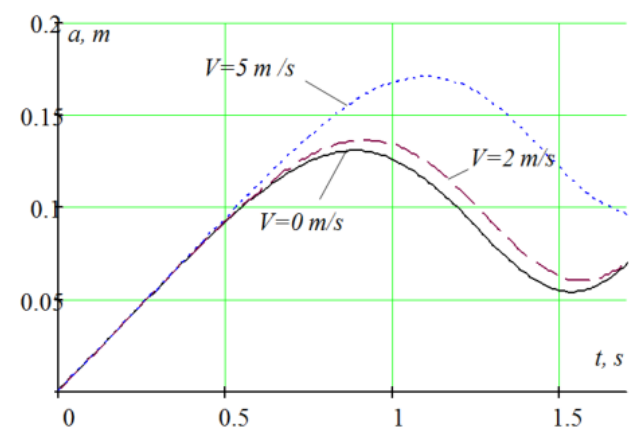

$N=100, l=6, m=15 m_{1}=10, \omega=8.432 \Omega=16.988$

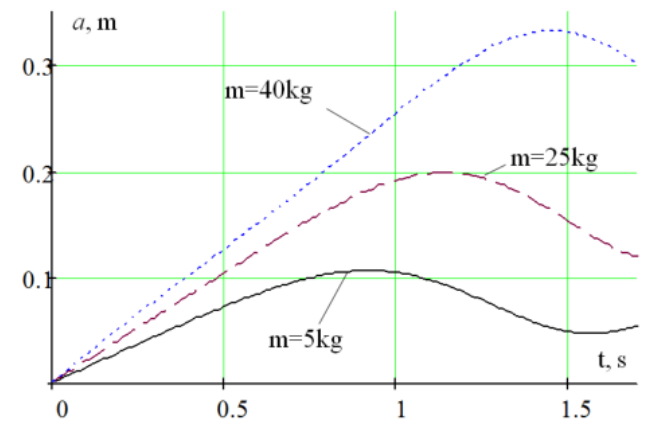

$N=100, l=6, m_{1}=10, V=4, \omega=10.886, \omega=7.126$, $\omega=5.962 \Omega=21.931 ; \Omega=15.335 ; \Omega=12.012$

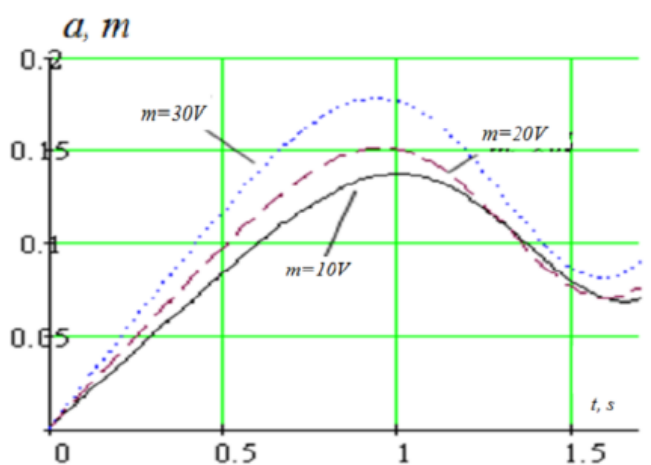

$N=100, l=6, m=50, m_{1} 10 \omega=9.427$, $\omega=7.697, \omega=6.666$

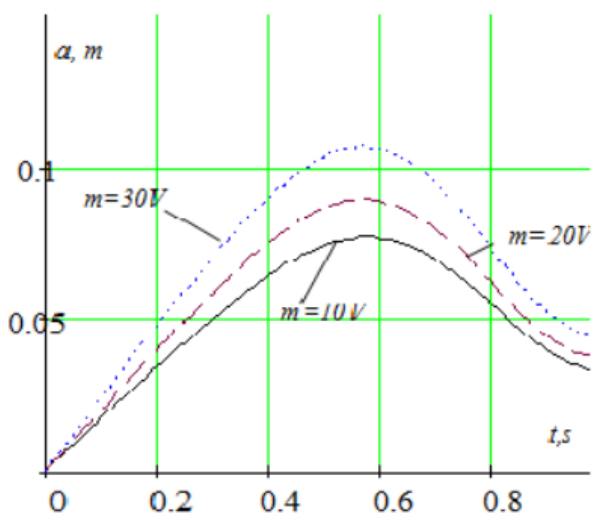

$N=100, l=6, m V=30, m_{1}=10, \omega=9.427$, $\omega=7.697, \omega=6.666$

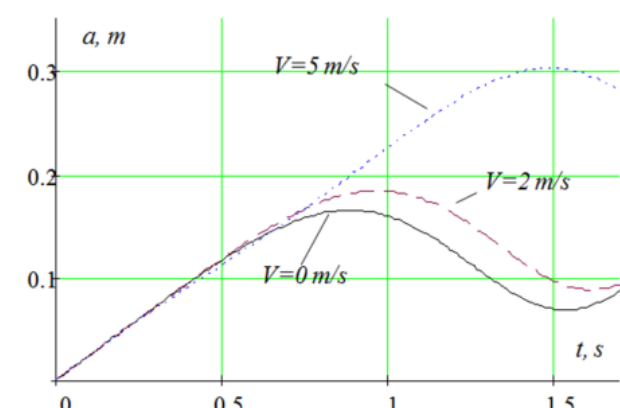

$N=100, l=6, m=30 m_{1}=10, \omega=6.6632 \Omega=13.14$

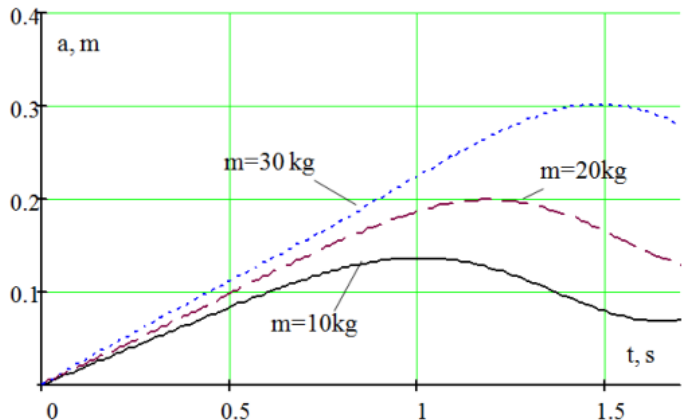

$N=100, l=6, m_{1}=10, V=5, \omega=9.4279$

$\omega=7.697 ; \omega=6.766$

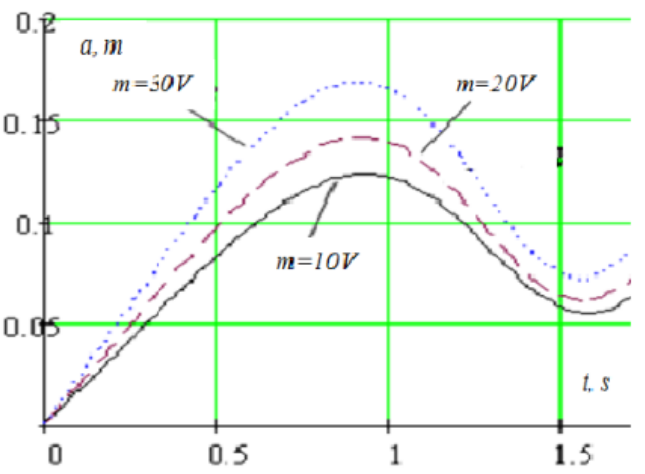

$N=100, l=6, m V=30 m_{1}=10 \omega=9.427$,

$\omega=7.697, \omega=6.666$

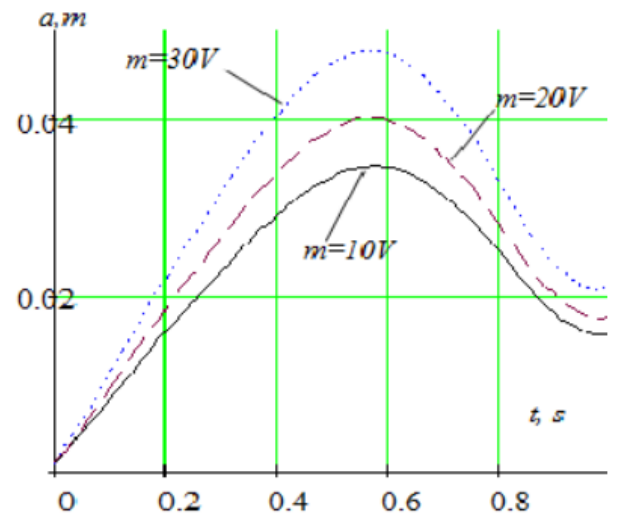

$N=100, l=4, m V=30, m_{1}=10$

$\omega=21.22, \omega=17.331, \omega=15.011$

Figure 3. Changes in time of the amplitude of the multifunctional conveyor working body during the transition through the main resonance 


\section{Conclusions}

The developed analytical and graphic dependences prove that for the resonant case:

- the amplitude of the transition through the main resonance is greater for larger velocity values of the processed medium relative motion. An increase in the relative velocity from 2 to $5 \mathrm{~m} / \mathrm{s}$ at the parameters $m=15 \mathrm{~kg} / \mathrm{m}, m_{1}=10 \mathrm{~kg} / \mathrm{m}$, causes an increase in the amplitude of the transition through the main resonance by $17 \%$, and at the parameters $m=30 \mathrm{~kg} / \mathrm{m}, m_{1}=10 \mathrm{~kg} / \mathrm{m}$, by $54 \%$.

- an increase in the mass per unit length of the processed medium at the constant relative velocity of its motion causes an increase in the amplitude of the transition through resonance. An increase in the mass per unit length from $25 \mathrm{~kg} / \mathrm{m}$ to $40 \mathrm{~kg} / \mathrm{m}$ at a relative velocity of its motion $4 \mathrm{~m} / \mathrm{s}$ causes an increase in the amplitude of the transition through the resonance by $61 \%$.

- in case of identical quantities of the processed medium relative motion, the amplitude of the transition through the main resonance is greater provided that the relative velocities of the motion are smaller

- the transition rate through the main resonance largely affects the magnitude of the resonance amplitude; and the amplitude is smaller for larger rates of transition through resonance.

In the non-resonant case, the attenuation rate of the transverse oscillations amplitude is greater for larger quantities of medium motion. The basic idea of the above methodology can be applied to the case of many inhomogeneous inclusions, as well as for torsional oscillations of the working body.

\section{References}

1 Goroshko O.A. On the longitudinal oscillations of a beam with a movable carriage / O.A. Goroshko // Applied mechanics. - 1978. - 14. - No. 8. - P. 70-78.

2 Dotsenko P.D. On the oscillations and stability of a straight pipeline/ P.D. Dotsenko // Applied mechanics. - 1971. - Vol. 3. - P. $85-91$.

3 Кошляков Н.С. Уравнения в частных производных математической физики / Н.С. Кошляков, О.Б. Гланер, М.М. Смирнов. - М.: Высш. шк., 1970. - 710 с.

4 Kauderer G. Nonlinear mechanics / G.Kauderer; пер. с нем. Ya.G. Panovko. - Moscow, 1961. - 777 p.

5 Hevko B.M. Modeling of fluctuations of the mechanical system 'suspension hole': theoretical analysis / B.M. Hevko, Yu.F. Pavelchuk // Innovative solutions in modern science. - 2017. - No. 1(10). - P. 1-9.

6 Gevko R.B. The investigation of the process of the actuation of the safety device of a screw conveyer / R.B. Gevko, O.M. Klendiy // INMATEH: Agricultural engineering. — 2014. — Vol. 42. — No. 1. P. 55-60. Bucharest, Romania.

7 Hevko R.B. Development and investigation of reciprocating screw with flexible helical surface / R.B. Hevko, S.Z. Zalutskyi, I.G. Tkachenko, O.M. Klendiy // INMATEH: Agricultural engineering. - 2015. Vol. 46. - No. 2. - P. 133-138.

8 Hevko R.B. Investigation of a transfer branch of a flexible screw conveyer / R.B. Hevko, M.B. Klendii, O.M. Klendii // INMATEH: Agricultural engineering. - 2016. - Vol. 48. - No. 1. - P. 29-34. Bucharest, Romania.

9 Hevko R.B. Development of design and investigation of operation processes of loading pipes of screw conveyors / R.B. Hevko, R.I. Rozum, O.M Klendiy // INMATEH: Agricultural engineering, - 2016. Vol. 50. - No. 3. - P. 89-96. Bucharest, Romania.

10 Hevko R.B. Feasibility study of the process of transpotration and stirring of mixture in continuous-flow conveyers / R.B. Hevko, B.O. Yazlyuk, M.V. Liubin, O.A. Tokarchuk, O.M. Klendii, V.R. Pankiv // INMATEH: Agricultural engineering. - 2017. - Vol. 51. - No. 3. - P. 49-58. Bucharest, Romania.

11 Stotsko Z.A. Complex mathematical model and optimization of vibration volumetric treatment for surfaces of maschine parts / Z. Stotsko, B. Sokil, V. Topilnytskyj // J. of Achievements in Materials and Manufacturing Engineering. - 2007, September. - Vol. 24. - P. 283-290.

12 Stotsko Z. Das Unlinear parametrisch modell der Dreimassenmaschienen fur die Vibrations volumen behandlung und ihre Streuladung / Z. Stotsko, B. Sokil, V. Topilnytskyj // Kwartalnik Naukowo-Techniczny Maszyny dzwigowo-transportowe. - Bytom, Poland, 2000. - No. 3. - P. 50-62. 
13 Geruk S.M. Influence of oscillations perturbations of the vibration separator on the dynamics of the grain mixture / S.M. Geruk, A.P. Dovysh. Construction, production and operation of agricultural machinery. - 2016. - 46. - P. 124-132.

14 Бабаков И.М. Теория колебаний / И.М. Бабаков. - М.: Наука, 1965. - 560 с.

15 Боголюбов Н.Н. Асимптотические методы теории нелинейных колебаний / Н.Н. Боголюбов, Ю.А. Митропольский. - М.: Наука, 1974. - 504 с.

16 Митропольский Ю.А. Асимптотические решения уравнений в частных производных / Ю.А. Митропольский, Б.Н. Мосеенков. - Киев: Вища школа, 1976. - 592 с.

Б.Гевко, О.Ляшук, М.Сокил, Е.Скиба, А.Маруныч, Д.Шматко

\title{
Көпфункционалды конвейердің жұмыс элементінің динамикасы
}

\begin{abstract}
Көп функционалдық транспортердің жұмыс қаруының иілген тербелісінің математикалық моделі алынған, мұнда транспортер айналымының бұрыштық жылдамдығы мен сыртқы ортаның оның бойымен жылжыуы ескерілген. Алынған нәтиженің негізінде резонасты және бейрезонансты жағдайлары үшін оның тербелісін анықтайтын параметрлердің өзгеру заңдылықтарын айқындайтын аналитикалық қатынастар алынған. Резонанс арқылы өту амплитудасы ортаның жылжу санына және резонанс арқылы өту жылдамдығына тәуелді.
\end{abstract}

Kiлm сөздер: динамикалық модельдеу, амплитуда, резонанс, транспортер, параметрлерді айқындау, айналу жылдамдығы.

\author{
Б.Гевко, О.Ляшук, М.Сокил, Е.Скиба, А.Маруныч, Д.Шматко
}

\section{Динамика шнекового рабочего органа многофункционального транспортера}

\begin{abstract}
Получена математическая модель изгибных колебаний рабочего органа многофункционального транспортера с учетом угловой скорости его вращения и движения вдоль него наружной среды. На ее базе получены аналитические соотношения, описывающие законы изменения определяющих параметров его колебаний как для нерезонансного, так и для резонансного случаев. Установлено, что амплитуда перехода через резонанс в значительной степени зависит от относительного количества движения среды и скорости перехода через резонанс.
\end{abstract}

Ключевые слова: динамическое моделирование, амплитуда, резонанс, транспортер, определяющие параметры, скорость вращения.

\section{References}

1 Goroshko, O.A. (1978). On the longitudinal oscillations of a beam with a movable carriage. Applied mechanics, Vol. 14, 8, 70-78.

2 Dotsenko, P.D. (1971). On the oscillations and stability of a straight pipeline. Applied mechanics, Vol. 3, $85-91$.

3 Koshliakov, N.S., Glainer, Ye.B., \& Smirnov, M.M. (1970). Uravneniia v chastnykh proizvodnykh matematicheskoi fiziki [Equations in partial derivatives of mathematical]. Moscow: Vysshaia shkola [in Russian].

4 Kauderer, G. (1961). Nonlinear mechanics. (Ya.G. Panovko, Trans.). Moscow.

5 Hevko, B.M., \& Pavelchuk, Yu.F. (2017). Modeling of fluctuations of the mechanical system 'suspension hole': theoretical analysis. Innovative solutions in modern science, 1(10), 1-9. 
6 Gevko, R.B., \& Klendiy, O.M. (2014). The investigation of the process of the actuation of the safety device of a screw conveyer. INMATEH: Agricultural engineering, Vol. 42, 1, 55-60. Bucharest, Romania.

7 Hevko, R.B., Zalutskyi, S.Z., Tkachenko, I.G., \& Klendiy, O.M. (2015). Development and investigation of reciprocating screw with flexible helical surface. INMATEH: Agricultural engineering, Vol. 46, 2, $133-138$.

8 Hevko, R.B., Klendii, M.B., \& Klendii, O.M. (2016). Investigation of a transfer branch of a flexible screw conveyer. INMATEH: Agricultural engineering, Vol. 48, 1, 29-34. Bucharest, Romania.

9 Hevko, R.B., Rozum, R.I., \& Klendiy, O.M. (2016). Development of design and investigation of operation processes of loading pipes of screw conveyors. INMATEH: Agricultural engineering, Vol. 50, 3, 89-96. Bucharest, Romania.

10 Hevko, R.B., Yazlyuk, B.O., Liubin, M.V., Tokarchuk, O.A., Klendii, O.M., \& Pankiv, V.R. (2017). Feasibility study of the process of transpotration and stirring of mixture in continuous-flow conveyers. INMATEH: Agricultural engineering, Vol. 51, 3, 49-58. Bucharest, Romania.

11 Stotsko, Z., Sokil, B., \& Topilnytskyj, V. (2007). Complex mathematical model and optimization of vibration volumetric treatment for surfaces of maschine parts. Journal of Achievements in Materials and Manufacturing Engineering, Vol. 24, September, 2007, 283-290.

12 Stotsko, Z., Sokil, B., \& Topilnytskyj, V. (2000). Das Unlinear parametrisch modell der Dreimassenmaschienen fur die Vibrations volumen behandlung und ihre Streuladung. Kwartalnik naukowo-Techniczny Maszyny dzwigowo-transportowe, No. 3, 50-62. Bytom, Poland.

13 Geruk, S.M., \& Dovysh, A.P. (2016). Influence of oscillations perturbations of the vibration separator on the dynamics of the grain mixture. Construction, production and operation of agricultural machinery, 46, 124-132.

14 Babakov, I.M. (1965). Teoriia kolebanii [Theory of oscillations]. Moscow: Nauka [in Russian].

15 Bogoliubov, N.N., \& Mitropolskiy, Yu.A. (1974). Asimptoticheskie metody teorii nelineinykh kolebanii [Asymptotic methods in the theory of nonlinear]. Moscow: Nauka [in Russian].

16 Mitropolskiy, Yu.A., \& Moseyenkov, B.I. (1976). Asimptoticheskie resheniia uravnenii v chastnykh proizvodnykh [Asymptotic solutions of partial differential equations]. Kiev: Vyssha shkola [in Russian]. 